\title{
Intake, microbial protein synthesis, and nitrogen balance in lambs fed diets containing mulberry hay
}

\section{Consumo, síntese de proteína microbiana e balanço de nitrogênio em cordeiros alimentados com dietas contendo feno de amoreira}

\author{
Luís Gabriel Alves Cirne ${ }^{1 *}$; Américo Garcia da Silva Sobrinho²; \\ Fernanda Carvalho Basso ${ }^{3}$; Roque Takahashi²; Thiago Henrique Borghi"; \\ Carlos Renato Viegas ${ }^{4}$; Gleidson Giordano Pinto de Carvalho; \\ Nivea Maria Brancacci Lopes Zeola ${ }^{6}$
}

\begin{abstract}
The objective of this study was to evaluate intake, microbial protein synthesis, and nitrogen balance in lambs fed diets containing $0.00,12.50$, and $25.00 \%$ mulberry hay substituting the concentrate. Twentyfour Ile de France lambs at approximately 60 days of age, with a body weight of $15.48 \pm 0.07 \mathrm{~kg}$, were confined in individual stalls and slaughtered upon reaching $32 \mathrm{~kg}$ body weight. Only the intakes of ether extract and metabolizable energy decreased linearly $(\mathrm{P}<0.05)$ as the participation of mulberry hay in the concentrate was increased. Nitrogen in the feces, expressed in $\mathrm{g} \mathrm{day}^{-1}$ and $\mathrm{g} \mathrm{kg}^{0.75} \mathrm{day}^{-1}$, increased linearly $(\mathrm{P}<0.05)$, whereas excretions $\left(\mathrm{mmol} \mathrm{day}^{-1}\right)$ of allantoin, total purines, and absorbed microbial purines, microbial production $\left(\mathrm{g} \mathrm{day}^{-1}\right)$ expressed in microbial nitrogen and microbial crude protein, and microbial efficiency expressed in $\mathrm{g} \mathrm{M}_{\mathrm{N}} \mathrm{kg}^{-1} \mathrm{RDOM}^{-1}$ and $\mathrm{g} \mathrm{M}_{\mathrm{P}} \mathrm{kg}^{-1}$ of TDN decreased linearly as the level of hay in the diet was increased. Mulberry hay substituting the concentrate in diets for feedlot lambs reduces the microbial protein synthesis.
\end{abstract}

Key words: Alternative feed, feedlot, metabolism, sheep

\section{Resumo}

Objetivou-se com este trabalho avaliar o consumo, a síntese de proteína microbiana e o balanço de nitrogênio em cordeiros alimentados com rações contendo 0,$00 ; 12,50$ e $25,00 \%$ de feno de amoreira em substituição ao concentrado. Foram utilizados vinte e quatro cordeiros Ile de France, com aproximadamente 60 dias de idade e 15,48 $\pm 0,07 \mathrm{~kg}$ de peso corporal, confinados em baias individuais e abatidos ao atingirem $32 \mathrm{~kg}$ de peso corporal. Apenas a ingestão de extrato etéreo e energia metabolizável apresentaram redução linear $(\mathrm{P}<0,05)$ com a inclusão do feno de amoreira no concentrado. Houve aumento linear $(\mathrm{P}<0,05)$ do nitrogênio nas fezes expresso em $\mathrm{g}$ dia $^{-1}$ e $\mathrm{g} \mathrm{kg}^{0,75} \mathrm{dia}^{-1}$, redução linear $(\mathrm{P}<0,05)$ das excreções $\left(\mathrm{mmol} \mathrm{dia}^{-1}\right)$ de alantoína, purinas totais e purinas microbianas absorvidas,

\footnotetext{
${ }^{1}$ Prof. e Pesquisador, Universidade Federal de Roraima, UFRR, Boa Vista, RR, Brasil. E-mail: lgabrielcirne@hotmail.com

2 Profs. e Pesquisadores, Universidade Estadual Paulista, UNESP, Jaboticabal, SP, Brasil. E-mail: americo@fcav.unesp.br; takahashi@fcav.unesp.br

${ }^{3}$ Discente do curso de Doutorado, Universidade Estadual Paulista, UNESP, Jaboticabal, SP, Brasil. E-mail: fcarvalhobasso@, yahoo.com.br

4 Discentes do curso de Mestrado, UNESP, Jaboticabal, SP, Brasil. E-mail: thiagoborghi@zootecnista.com.br; viegascr@ zootecnista.com.br

5 Prof. e Pesquisador, Universidade Federal da Bahia, UFBA, Salvador, BA, Brasil. E-mail: gleidsongiordano@yahoo.com.br

6 Pesquisadora, UNESP, Jaboticabal, SP, Brasil. E-mail: nivea.brancacci@ig.com.br

Author for correspondence
} 
produção microbiana $\left(\mathrm{g} \mathrm{dia}^{-1}\right)$ expressa em nitrogênio microbiano e proteína bruta microbiana, e eficiência microbiana expressa em $\mathrm{g} \mathrm{Nm} \mathrm{kg}^{-1}$ de $\mathrm{MODR}^{-1}$ e $\mathrm{g} \mathrm{Pm} \mathrm{kg}^{-1}$ de NDT à medida que aumentou feno de amoreira na ração. $\mathrm{O}$ feno de amoreira em substituição ao concentrado na ração de cordeiros confinados reduz a síntese de proteína microbiana.

Palavras-chave: Alimento alternativo, confinamento, metabolismo, ovinos

\section{Introduction}

In ruminant production systems, either on pasture or in the feedlot, the feed intake is an essential process that determines the uptake of nutrients to meet the requirements for the maintenance and performance of an animal (DETMANN et al., 2003). In this regard, maximizing animal production has been the target of studies aimed at determining the efficient use of nutrients and consequent the nutritional value of feedstuffs (AZEVÊDO et al., 2011; GERON et al., 2013).

The nutritional quality of diets is an essential parameter to obtaining satisfactory performance in ruminants, and one of the ways to evaluate it is by quantifying the synthesis of microbial protein. The protein requirements of ruminants are met by the intestinal absorption of amino acids that originate mainly from the microbial protein synthesized in the rumen and the dietary protein undegraded in the rumen. The microbial protein synthesis in the rumen can supply 50 to $100 \%$ of the metabolizable protein required by ruminants (RIBEIRO et al., 2014).

Determining the nitrogen balance is a technique utilized to quantify retentions or losses of nitrogen by the animal body, which varies according to the difference between the nitrogen consumed and the nitrogen excreted in feces and urine (ZEOULA et al., 2003). This variable is indicative of gains or losses of protein by the animals fed different diets. Thus, the nitrogen balance is an important trait to evaluate the efficiency of use of nitrogen by ruminants and its losses to the environment (GENTIL et al., 2007).

The mulberry (Morus sp.) belongs to the family Moraceae, and it is used as a forage in ruminant feeding is because of its grass-related features such as adaptation to different soils and climates; green mass production of 25 to $30 \mathrm{t} / \mathrm{ha} / \mathrm{yr}$; crude protein content of 18 to $28 \%$; total digestible nutrients content of 76\%; good acceptability; and dry matter digestibility of 75 to $85 \%$ (SANCHEZ, 2002; BA et al., 2005; BAMIKOLE et al., 2005), and these aspects characterize this plant as an important alternative feedstuff.

The objective of this study was to evaluate intake, microbial protein synthesis, and nitrogen balance of lambs fed diets containing mulberry hay.

\section{Material and Methods}

The field experiment complied with the ethical principles of animal experimentation adopted by the Brazilian College of Animal Experimentation (COBEA), and was approved by the Ethics Committee on the Use of Animals (CEUA) of the Faculty of Agriculture and Veterinary Sciences, FCAV - Unesp, protocol \# 014105/11.

The experiment was conducted in the sheep farming section of the Department of Animal Science of FCAV - Unesp, Jaboticabal Campus, SP, Brazil. Twenty-four newly weaned Ile de France lambs at approximately 60 days of age and with an initial body weight of $15.48 \pm 0.07 \mathrm{~kg}$ were used in the period from May to August 2011.

The experiment lasted 80 days, corresponding to 14 days for adaptation and 66 days for data collection. Animals were housed in individual wooden sheepfold stalls measuring approximately $1.0 \mathrm{~m}^{2}$, with suspended slatted floor, provided with individual feeder and drinkers, located inside a well-ventilated, covered shed. At the onset of the experiment, lambs were identified, subjected to the 
control of ectoparasites, immunized with polyvalent vaccine against clostridioses, supplemented with vitamins $\mathrm{A}, \mathrm{D}$, and $\mathrm{E}$ intramuscularly, and distributed into the treatments at random.

Experimental diets (Table 1) were calculated to meet the requirements recommended by NRC
(2007) for weaned lambs with an average gain of 300 $\mathrm{g} \mathrm{day}^{-1}$. Treatments consisted of the following diets: T1: sugarcane + concentrate without mulberry hay; T2: sugarcane + concentrate with $12.5 \%$ mulberry hay; and T3: sugarcane + concentrate with $25.0 \%$ mulberry hay, the sugarcane composing $50 \%$ of the total diet.

Table 1. Centesimal composition of ingredients and chemical composition of experimental diets.

\begin{tabular}{lccc}
\hline \multicolumn{1}{c}{ Composition } & \multicolumn{2}{c}{ Mulberry hay (\%) } \\
\cline { 2 - 4 } Centesimal (\%) & 0.00 & 12.50 & 25.00 \\
Sugarcane & 50.00 & 50.00 & 50.00 \\
Mulberry hay & - & 12.50 & 25.00 \\
Soybean meal & 28.49 & 24.60 & 21.33 \\
Ground corn & 17.80 & 9.00 & 0.00 \\
Soybean oil & 1.00 & 1.00 & 1.00 \\
Urea & 0.80 & 0.80 & 0.80 \\
Mineral-vitamin supplement ${ }^{1}$ & 0.50 & 0.50 & 0.50 \\
Calcitic limestone & 0.47 & 0.43 & 0.25 \\
Dicalcium phosphate & 0.94 & 1.17 & 1.12 \\
Chemical (DM basis) & & & \\
Dry matter & 58.44 & 56.94 & 57.18 \\
Organic matter & 93.63 & 92.56 & 91.92 \\
Crude protein & 18.88 & 18.51 & 18.40 \\
Ether extract & 2.88 & 2.55 & 2.21 \\
Lignin & 2.07 & 2.19 & 2.32 \\
Neutral detergent fiber ${ }^{2}$ & 23.56 & 24.26 & 25.01 \\
Acid detergent fiber & 16.54 & 17.20 & 17.92 \\
Total carbohydrates & 73.27 & 72.95 & 72.76 \\
Non-fiber carbohydrates & 53.57 & 52.74 & 51.57 \\
Total digestible nutrients (\%) & 79.11 & 76.61 & 73.58 \\
Metabolizable energy (Mcal/kg DM) & 2.99 & 2.95 & 2.55 \\
\hline
\end{tabular}

${ }^{1}$ Guaranteed levels per $\mathrm{kg}$ of product: calcium $120 \mathrm{~g}$, chlorine $90 \mathrm{~g}$, cobalt $10 \mathrm{mg}$, copper $50 \mathrm{mg}$, sulfur $34 \mathrm{~g}$, iron 1,064 mg, phosphorus $50 \mathrm{~g}$, iodine $25 \mathrm{mg}$, magnesium $54 \mathrm{~g}$, manganese 1,500 mg, selenium 20mg, sodium $62 \mathrm{~g}$ and zinc 1,600 mg, fluorine (max) 0.73 g, vitamin A 100,000 IU, vitamin D3 40,000 IU and vitamin E $600 \mathrm{IU} ;{ }^{2}$ corrected for ash and protein.

The sugarcane cultivar utilized was forage variety IAC 86-2480, which was harvested and chopped daily to $1.0 \mathrm{~cm}$ particles and supplied fresh. Mulberry branches originating from the silkworm facility in the Sericulture Section at FCAV - Unesp were cut at 60 days of regrowth, and later dried in the sun until reaching the hay point below $20 \%$ moisture (COSTA; RESENDE, 2006). After hayed, this material was ground utilizing a $0.8-\mathrm{mm}$ screen sieve aiming to facilitate the uniformity of the material when it would be mixed with the ingredients of the concentrate and prevent selectivity by the animals. 
The feed was supplied in two daily meals: $50 \%$ at $07 \mathrm{~h} 00$, and the other $50 \%$ at $17 \mathrm{~h} 00$, so as to allow at least $10 \%$ as orts. Feed supplied and orts were weighed daily after the 14-day period of adaptation to stalls and diets.

During the feedlot period, samples of the ingredients that composed the diet (Table 2), feed supplied, and orts were collected and pre-dried in a forced-air oven at $55^{\circ} \mathrm{C}$ for $72 \mathrm{~h}$ and subsequently ground in a Wiley mill with $1-\mathrm{mm}$ sieve for determination of the dry matter (DM), organic matter $(\mathrm{OM})$, mineral matter $(\mathrm{MM})$, ether extract (EE), and gross energy (GE) contents (SILVA; QUEIROZ, 2002). The total nitrogen content in the samples was obtained by the Dumas combustion method, utilizing a LECO FP-528 LC analyzer (ETHERIDGE et al., 1998) and multiplying the result by 6.25 to obtain the total crude protein (CP) value. Concentrations of lignin, neutral detergent fiber corrected for ash and protein (NDFap), and acid detergent fiber (ADF) were determined according to Van Soest (1994) and as recommended by the manufacturer of ANKOM Technology ${ }^{\circledR}$, using ANKOM bags. Total carbohydrates (TC) were calculated by the following equation: $\mathrm{TC}=$ $100-(\% \mathrm{CP}+\% \mathrm{EE}+\% \mathrm{MM})$ and the non-fiber carbohydrates (NFC) were estimated through an adaptation of the formula proposed by Hall (2000): $\mathrm{NFC}=100-[(\% \mathrm{CP}-\mathrm{CPu}+\mathrm{U})+\% \mathrm{EE}+\% \mathrm{MM}+$ $\% \mathrm{NDFap}]$, where $\mathrm{CPu}$ is the $\mathrm{CP}$ content from urea $(\%)$, and $U$ is the urea content $(\%)$.

Table 2. Chemical composition of the ingredients in the experimental diets.

\begin{tabular}{lcccc}
\hline \multicolumn{1}{c}{ Nutrient } & Sugarcane & Mulberry hay & Ground corn & Soybean meal \\
\hline Dry matter & 27.12 & 89.36 & 89.12 & 89.05 \\
Organic matter $^{1}$ & 97.70 & 89.45 & 97.79 & 92.37 \\
Crude protein $^{1}$ & 2.92 & 20.92 & 14.26 & 44.28 \\
Ether extract $^{1}$ & 0.38 & 2.64 & 6.75 & 1.74 \\
Lignin $^{1}$ & 2.28 & 2.69 & 1.40 & 2.40 \\
Neutral detergent fiber $^{1,2}$ & 33.72 & 21.99 & 17.75 & 12.42 \\
Acid detergent fiber $^{1}$ & 22.75 & 15.47 & 4.80 & 8.54 \\
Total carbohydrates $^{1}$ & 92.80 & 65.89 & 76.78 & 46.35 \\
Non-fiber carbohydrates $^{1}$ & 60.56 & 45.38 & 60.51 & 35.41 \\
Gross energy (Mcal/kg DM) & 4.29 & 4.54 & 4.65 & 4.73 \\
\hline
\end{tabular}

${ }^{1}$ in $\% ;{ }^{2}$ corrected for ash and protein.

The total digestible nutrients (TDN) content was obtained by the summative equation $\mathrm{TDN}=\mathrm{DCP}$ $+2.25 \times \mathrm{DEE}+\mathrm{DNDFap}+\mathrm{DNFC}$, where DCP, DEE, DNDFap, and DNFC mean, respectively, digestible crude protein, digestible ether extract, digestible neutral detergent fiber (free of ash and protein), and digestible non-fiber carbohydrates. The metabolizable energy (ME) was obtained from the digestibility trial and from the estimate of gas production in the rumen, by the following formula: $\mathrm{ME}=\mathrm{GEi}-(\mathrm{GEf}+\mathrm{GEu}+\mathrm{EGP})$, where GEi is the gross energy intake, GEf is the gross energy in the feces, GEu is the gross energy in the urine; and EGP is the energy for gas production, which was obtained by the following formula: EGP $=$ DGP $\times$ GEi $/ 100$, with $\mathrm{DGP}=4.28+0.059 \mathrm{DG}$, where DG is the digestibility of the energy in percentage (SNIFFEN et al., 1992).

Forty-five days after the beginning of the performance trial, 15 lambs from the 24 experimental units, with an average body weight (BW) of 25.87 
$\pm 1.50 \mathrm{~kg}$, were used in the trial to evaluate intake, microbial protein synthesis, and nitrogen balance. Lambs were housed in individual metabolic cages for 12 days, in which the first seven days were used for the animals to adapt to the cages, and the other five for total feces and urine collection.

Twenty-four hours after each collection day, the entire fecal production was gathered in plastic bowls, and the urine was placed in plastic buckets containing $100 \mathrm{~mL}$ of a $20 \%$ sulfuric acid $\left(\mathrm{H}_{2} \mathrm{SO}_{4}\right)$ solution to acidify it and prevent losses by volatilization of the ammonia to be measured. Of the total feces and urine excreted, 10\% were sampled and stored in a freezer at $-18{ }^{\circ} \mathrm{C}$. At the end of the nitrogen balance trial, a composite sample was collected per animal. Dry matter and total nitrogen contents were determined in the feces samples, while DM, total nitrogen, and GE contents were determined in the urine samples (SILVA; QUEIROZ, 2002).

Nutrient intake was calculated as the difference between the amount of the nutrient present in the feeds supplied and the amount of that nutrient in the orts during the trial period, according to the following formula: Intake $(\mathrm{kg})=$ nutrient ingested - nutrient in the orts. The apparent nitrogen balance (NB) was calculated by the following formulae, expressed in $\mathrm{g}_{\text {day }}{ }^{-1}$ and in $\mathrm{g} \mathrm{kg}^{0.75} \mathrm{day}^{-1}$ : NB or $\mathrm{N}_{\text {retained }}=\mathrm{N}_{\text {intake }}-\left(\mathrm{N}_{\text {feces }}+\mathrm{N}_{\text {urine }}\right) ; \mathrm{N}_{\text {absorbed }}=\mathrm{N}_{\text {intake }}-$ $\mathrm{N}_{\text {feces }}$ and $\mathrm{N}_{\text {intake }}=\mathrm{N}_{\text {supplied }}-\mathrm{N}_{\text {orts }}$.

During the period of urine collection, spot samples were taken during spontaneous urination, at $11 \mathrm{~h} 00$, i.e., four hours after the supply of the meal at $07 \mathrm{~h} 00$. A $10-\mathrm{mL}$ aliquot of the urine was diluted in $40 \mathrm{~mL} 0.036 \mathrm{~N}$ sulfuric acid, and after this process, the $\mathrm{pH}$ was adjusted, if necessary, to values below 3 , with droplets of concentrate sulfuric acid, aiming to prevent bacterial destruction of the purine derivatives and precipitation of the uric acid. Samples were stored at $-18{ }^{\circ} \mathrm{C}$ for later analyses of the purine derivatives allantoin, uric acid, xanthine, and hypoxanthine.
Analyses of these derivatives were performed by the technique described by Chen and Gomes (1992). Absorbed microbial purines (X, mmol day ${ }^{-1}$ ) were calculated from the excretion of purine derivatives ( $\mathrm{Y}, \mathrm{mmol} /$ day), by the following equation: $\mathrm{Y}=0.84 \mathrm{X}$ $+\left(0.150 \mathrm{BW}^{0.75} \mathrm{e}^{-0.25 \mathrm{X}}\right)$, where 0.84 is the recovery of absorbed purines as urinary purine derivatives, and $0.150 \mathrm{BW}^{0.75} \mathrm{e}^{-0.25 \mathrm{X}}$ is the endogenous contribution to the excretion of purines (VERBIC et al., 1990) The intestinal flow of nitrogen compounds (Y,

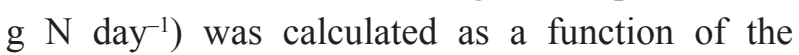
absorbed microbial purines $\left(\mathrm{X}, \mathrm{mmol}\right.$ day $\left.^{-1}\right)$, using the following equation: $\mathrm{Y}=(70 \mathrm{X}) /(0.83 \times 0.116 \times$ 1000 ), where 70 is the $\mathrm{N}$ content in the purines ( $\mathrm{mg}$

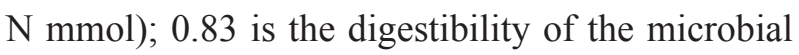
purines; and 0.116 is the Purine N:Total bacterial $\mathrm{N}$ ratio. Microbial production was expressed as $\mathrm{g}$ microbial $\mathrm{N}$ (grams of microbial $\mathrm{N}$ ) and $\mathrm{g}$ microbial $\mathrm{P}$ (grams of microbial protein), and the microbial efficiency was expressed as $\mathrm{g} \mathrm{M}_{\mathrm{N}} \mathrm{kg}^{-1}$ RDOM (grams of microbial nitrogen per kilogram of rumen-degraded organic matter) and $\mathrm{g} \mathrm{M}_{\mathrm{p}} \mathrm{kg}^{-1}$ TDN (grams of microbial protein per kilogram of total digestible nutrients consumed).

The experimental design was randomized blocks with three treatments and five replicates, totaling 15 experimental units. Results were evaluated by analysis of variance and regression, with degrees of freedom broken down into linear or quadratic effects, according to the percentages of mulberry hay. The significance of the regressions was obtained by the $\mathrm{F}$ test at 1 or $5 \%$ probability using the Sisvar statistical software (FERREIRA, 2011), employing the mathematical model below:

$$
\text { Yij }=\mu+\mathrm{Ti}+\mathrm{Pj}+\mathrm{eij} \text {, where: }
$$

Yij = observed value of the variable studied in individual $\mathrm{j}$, receiving treatment $\mathrm{i}$;

$\mu=$ overall mean;

$\mathrm{Ti}=$ effect of treatment $\mathrm{i}$, varying from 1 to 3 $(0.00,12.50$, and $25.00 \%$ of inclusion of mulberry 
hay in the concentrate);

$\mathrm{Pj}=$ effect of period $\mathrm{j}(\mathrm{j}=1,2, \ldots, 5)$;

eij $=$ random effect associated with each observation.

\section{Results and Discussion}

Inclusion of mulberry hay substituting partially the concentrate in the lamb diets did not influence $(\mathrm{P}>0.05)$ the intakes of dry matter $(\mathrm{DM})$, organic matter (OM), crude protein (CP), neutral detergent fiber (NDF), acid detergent fiber (ADF), total carbohydrates (TC), or non-fiber carbohydrates (TDN). However, a decrease was detected $(\mathrm{P}<0.05)$ in the intakes of ether extract $(\mathrm{EE})$ and metabolizable energy (ME) (Table 3). The intake of most of the nutrients was probably similar among the diets because DM intake was close, and also because the diets were similar in their chemical composition (Table 1). The decrease in EE intake is attributed to the greater content of this nutrient originating from ingredients like the corn, which had a higher participation in the control diet and in the diet containing $12.5 \%$ mulberry hay. Regarding the decrease in ME intake, it was caused by the reduction in the ME from the diet with $25 \%$ mulberry hay. However, the ME content of $2.55 \mathrm{Mcal} / \mathrm{kg} \mathrm{DM}$ of the diet with $25 \%$ inclusion of mulberry hay (Table 1) agrees with NRC (2007) for lambs with this weight $(25.87 \mathrm{~kg})$ and this production level (average daily weight gain of $300 \mathrm{~g} \mathrm{day}^{-1}$ ).

Table 3. Voluntary intake of nutrients $\left(\mathrm{g} \mathrm{day}^{-1}\right)$ and metabolizable energy (ME) by lambs fed diets containing differences percentages of mulberry hay.

\begin{tabular}{|c|c|c|c|c|c|c|}
\hline \multirow{2}{*}{ Intake } & \multicolumn{3}{|c|}{ Mulberry hay (\%) } & \multicolumn{2}{|c|}{ P-value ${ }^{1}$} & \multirow{2}{*}{$\mathrm{CV}(\%)^{2}$} \\
\hline & 0.00 & 12.50 & 25.00 & $\mathrm{~L}$ & Q & \\
\hline $\mathrm{DM}$ & 999.03 & 999.03 & $1,026.27$ & 0.571 & 0.948 & 5.49 \\
\hline $\mathrm{OM}$ & 935.33 & 940.00 & 943.33 & 0.855 & 0.986 & 5.48 \\
\hline $\mathrm{CP}$ & 188.66 & 188.00 & 189.00 & 0.970 & 0.914 & 5.56 \\
\hline $\mathrm{EE}^{3}$ & 28.66 & 26.00 & 22.66 & 0.004 & 0.778 & 6.20 \\
\hline NDF & 235.33 & 246.33 & 256.66 & 0.100 & 0.973 & 5.47 \\
\hline $\mathrm{ADF}$ & 165.00 & 174.66 & 184.00 & 0.055 & 0.982 & 5.61 \\
\hline $\mathrm{TC}$ & 732.00 & 740.33 & 746.66 & 0.674 & 0.973 & 5.49 \\
\hline NFC & 535.00 & 535.33 & 529.00 & 0.812 & 0.878 & 5.53 \\
\hline $\mathrm{ME}(\mathrm{Mcal} / \mathrm{kg} \mathrm{DM})^{4}$ & $2,992.00$ & $3,001.33$ & $2,616.33$ & 0.031 & 0.140 & 5.72 \\
\hline
\end{tabular}

${ }^{1}$ Effect: $\mathrm{L}=$ linear and $\mathrm{Q}=$ quadratic $;{ }^{2} \mathrm{CV}=$ coefficient of variation; ${ }^{3} \mathrm{Y}=28.777778-0.240000 \mathrm{x} . \mathrm{R}^{2}=0.99 ;{ }^{4} \mathrm{Y}=3057.722222-$ $15.026667 x . R^{2}=0.99$.

The microbial protein synthesis was modified by the inclusion of mulberry hay in the animal diets (Table 4). Excretions of allantoin and total purines, absorbed microbial purines, microbial production (expressed in microbial $\mathrm{N}$ and microbial $\mathrm{CP}$ ), and microbial efficiency (expressed in $\mathrm{g} \mathrm{M}_{\mathrm{N}} \mathrm{kg}^{-1} \mathrm{RDOM}$ and $\left.\mathrm{g}_{\mathrm{P}} \mathrm{kg}^{-1} \mathrm{TDN}\right)$ decreased linearly $(\mathrm{P}<0.05)$. The reduction in microbial protein synthesis by the animals fed diets containing mulberry hay may be related to the lack of synchronism between protein and energy due to the rapid degradation of this forage, which contains up to $74 \%$ of fractions A and B (SNIFFEN et al., 1992; BRODERICK, 1995; SILVA, 2015), besides the substitution of ground corn for the mulberry hay, in which starch is the main source of carbohydrates readily available for microbial growth (HOOVER; MILLERWEBSTER, 1998). 
Evaluating the in vitro degradation kinetics of the protein and carbohydrate fractions in mulberry leaves, Silva (2015) concluded that in diets containing mulberry leaves the animal should be given an easily degradable carbohydrate source, to optimize the use of the protein present in the mulberry. Likewise, Gomes (2012) studied the production and nutritional value of mulberry hybrids and reported that in diets with mulberry leaves the proportion of energy concentrates should be increased to maximize the microbial protein synthesis and reduce the loss of degraded protein.

According to Pereira et al. (2005) and Ribeiro et al. (2014), to optimize the microbial protein synthesis in the rumen, the ruminal microorganisms depend on carbon skeletons originating from neutral detergent fibers and non-fiber carbohydrates with rumen degradability that ensures the supply and appropriate availability of energy and a concomitant supply of ammonia, amino acids, and peptides in the biosynthetic process for the microbial protein synthesis to occur.

Table 4. Microbial protein synthesis of lambs fed diets containing mulberry hay.

\begin{tabular}{|c|c|c|c|c|c|c|}
\hline \multirow{2}{*}{ Variable } & \multicolumn{3}{|c|}{ Mulberry hay (\%) } & \multicolumn{2}{|c|}{ P-value ${ }^{1}$} & \multirow{2}{*}{$\mathrm{CV}(\%)^{2}$} \\
\hline & 0.00 & 12.50 & 25.00 & $\mathrm{~L}$ & Q & \\
\hline \multicolumn{7}{|c|}{ Urinary excretion $\left(\mathrm{mmol}\right.$ day $\left.^{-1}\right)$} \\
\hline Allantoin ${ }^{3}$ & 17.55 & 12.51 & 10.09 & 0.040 & 0.640 & 32.97 \\
\hline Uric acid & 2.92 & 2.65 & 2.12 & 0.113 & 0.801 & 26.27 \\
\hline Total purines ${ }^{4}$ & 20.52 & 15.17 & 12.21 & 0.029 & 0.676 & 28.37 \\
\hline \multicolumn{7}{|c|}{ Microbial purine $\left(\mathrm{mmol}\right.$ day $\left.^{-1}\right)$} \\
\hline Absorbed $^{5}$ & 24.43 & 18.05 & 14.54 & 0.029 & 0.676 & 28.38 \\
\hline \multicolumn{7}{|l|}{ Total purines $(\%)$} \\
\hline Allantoin & 85.01 & 82.03 & 81.26 & 0.409 & 0.775 & 7.40 \\
\hline Uric acid & 14.99 & 17.97 & 18.74 & 0.409 & 0.775 & 35.52 \\
\hline \multicolumn{7}{|l|}{ Microbial protein $\left(\mathrm{g} \mathrm{day}^{-1}\right)$} \\
\hline Microbial $\mathrm{N}^{6}$ & 17.71 & 13.06 & 10.44 & 0.029 & 0.685 & 28.73 \\
\hline Microbial $\mathrm{CP}^{7}$ & 110.71 & 81.66 & 65.29 & 0.029 & 0.685 & 28.73 \\
\hline \multicolumn{7}{|c|}{ Microbial efficiency $\left(\mathrm{g} \mathrm{day}^{-1}\right)$} \\
\hline RDOM & 571.18 & 622.26 & 636.02 & 0.490 & 0.816 & 20.89 \\
\hline $\mathrm{M}_{\mathrm{N}} \mathrm{kg}^{-1} \mathrm{RDOM}^{8}$ & 20.64 & 13.84 & 11.18 & 0.011 & 0.445 & 27.75 \\
\hline $\mathrm{M}_{\mathrm{p}} \mathrm{kg}^{-1} \mathrm{TDN}^{9}$ & 158.81 & 107.72 & 81.90 & 0.006 & 0.510 & 25.92 \\
\hline
\end{tabular}

${ }^{1}$ Effect: $\mathrm{L}=$ linear and $\mathrm{Q}=$ quadratic; ${ }^{2} \mathrm{CV}=$ coefficient of variation; ${ }^{3} \mathrm{Y}=17.121667-0.298600 \mathrm{x} . \mathrm{R}^{2}=0.96 ;{ }^{4} \mathrm{Y}=20.122917$ $-0.332300 x . R^{2}=0.97 ;{ }^{5} \mathrm{Y}=23.953750-0.395500 x . \mathrm{R}^{2}=0.97 ;{ }^{6} \mathrm{Y}=23.953750-0.290700 \mathrm{x} . \mathrm{R}^{2}=0.97 ;{ }^{7} \mathrm{Y}=108.600833-$ $1.817000 \mathrm{x} . \mathrm{R}^{2}=0.97 ;{ }^{8} \mathrm{Y}=19.951667-0.378200 \mathrm{x} . \mathrm{R}^{2}=0.94 ;{ }^{9} \mathrm{Y}=154.604167-3.076400 \mathrm{x} . \mathrm{R}^{2}=0.96$.

The nitrogen balance (Table 5) was positive in the animals receiving the three diets, with no influences $(\mathrm{P}>0.05)$ of treatments in the amounts of nitrogen ingested, excreted in urine, absorbed, or retained (nitrogen balance), possibly because the nitrogen concentration was similar among the diets
(Table 1). Nevertheless, the nitrogen in the feces increased linearly $(\mathrm{P}<0.05)$, probably due to the loss of $\mathrm{N}$ caused by the lack of synchronism between protein and energy, which resulted in a reduction of microbial protein synthesis by the animals fed diets containing mulberry hay (Table 4). 
This result was similar to that reported by Anbarasu et al. (2004), who evaluated the substitution of the protein from a soybean mealbased concentrate for feed containing mulberry hay in goat diets by the metabolism of nitrogen and did not observe differences $(\mathrm{P}>0.05)$ in nitrogen balance.

The excess degradable protein and the type of nitrogen source utilized in the diet may cause an increase in the amount of ammonia in the rumen, exceeding its ability of use by the rumen microbiota, and also reflect in the relationship between the $\mathrm{N}$ excreted via the urinary and fecal pathways. In this situation, the energy supply is usually the first limiting factor of rumen microbial growth (ZEOULA et al., 2003; CALDAS NETO et al., 2008; PINA et al., 2010).

Table 5. Apparent nitrogen balance in lambs fed diets containing mulberry hay.

\begin{tabular}{|c|c|c|c|c|c|c|}
\hline \multirow{2}{*}{ Variable } & \multicolumn{3}{|c|}{ Mulberry hay (\%) } & \multicolumn{2}{|c|}{ P-value ${ }^{1}$} & \multirow{2}{*}{$\mathrm{CV}(\%)^{2}$} \\
\hline & 0.00 & 12.50 & 25.00 & $\mathrm{~L}$ & Q & \\
\hline \multicolumn{7}{|l|}{ Nitrogen intake } \\
\hline $\mathrm{g}$ day $^{-1}$ & 38.84 & 44.52 & 39.58 & 0.865 & 0.183 & 15.32 \\
\hline $\mathrm{g} \mathrm{kg}^{0.75}$ day $^{-1}$ & 3.26 & 3.67 & 3.49 & 0.538 & 0.374 & 15.06 \\
\hline \multicolumn{7}{|l|}{ Nitrogen in feces } \\
\hline g day ${ }^{-13}$ & 5.96 & 6.00 & 8.48 & 0.029 & 0.186 & 20.92 \\
\hline $\mathrm{g} \mathrm{kg}^{0.75}$ day $^{-14}$ & 0.50 & 0.49 & 0.75 & 0.025 & 0.144 & 23.46 \\
\hline$\% \mathrm{~N}$ intake & 15.47 & 13.53 & 21.85 & 0.051 & 0.068 & 24.33 \\
\hline \multicolumn{7}{|l|}{ Nitrogen in urine } \\
\hline $\mathrm{g}_{\mathrm{day}}{ }^{-1}$ & 12.00 & 10.06 & 10.11 & 0.519 & 0.694 & 38.92 \\
\hline $\mathrm{g} \mathrm{kg}^{0.75}$ day $^{-1}$ & 1.01 & 0.82 & 0.89 & 0.629 & 0.564 & 38.89 \\
\hline$\% \mathrm{~N}$ intake & 33.80 & 25.39 & 29.76 & 0.563 & 0.301 & 33.55 \\
\hline \multicolumn{7}{|l|}{$\mathrm{N}$ absorbed } \\
\hline $\mathrm{g} \mathrm{day}^{-1}$ & 32.88 & 38.52 & 31.10 & 0.674 & 0.095 & 17.66 \\
\hline $\mathrm{g} \mathrm{kg}^{0.75}$ day $^{-1}$ & 2.76 & 3.17 & 2.74 & 0.957 & 0.178 & 17.06 \\
\hline \multicolumn{7}{|l|}{$\mathrm{N}$ retained } \\
\hline $\mathrm{g}_{\text {day }}^{-1}$ & 20.87 & 28.45 & 20.99 & 0.979 & 0.079 & 27.98 \\
\hline $\mathrm{g} \mathrm{kg}^{0.75}$ day $^{-1}$ & 1.74 & 2.34 & 1.85 & 0.790 & 0.129 & 28.39 \\
\hline$\% \mathrm{~N}$ intake & 50.71 & 61.07 & 48.38 & 0.776 & 0.126 & 17.75 \\
\hline $\mathrm{N}_{\text {retained }} / \mathrm{N}_{\text {intake }}$ & 0.54 & 0.64 & 0.51 & 0.711 & 0.140 & 21.14 \\
\hline $\mathrm{N}_{\text {retained }} / \mathrm{N}_{\text {absorbed }}$ & 0.64 & 0.74 & 0.65 & 0.531 & 0.347 & 19.47 \\
\hline
\end{tabular}

${ }^{1}$ Effect: $\mathrm{L}=$ linear and $\mathrm{Q}=$ quadratic $;{ }^{2} \mathrm{CV}=$ coefficient of variation; ${ }^{3} \mathrm{Y}=5.553333+0.100800 \mathrm{x}, \mathrm{R}^{2}=0.76 ;{ }^{4} \mathrm{Y}=0.456333+$ $0.010080 x, R^{2}=0.73$.

The evidence shown in this study corroborate Ezequiel et al. (2000), who studied the nitrogen balance and the total digestion of protein and energy from different diets and found that the uniform protein intake made it possible to observe probable differences in the quality of the protein sources utilized. However, also according to Ezequiel et al.
(2000), when compared with the absorbed nitrogen, the nitrogen balance reflects the use of nitrogen in the tissue protein synthesis for the development of new tissues, new enzymatic system, or to substitute old or epithelial tissues. The efficiency with which this activity is performed depends essentially on the nature and composition of the nitrogen compound 
that reaches the tissues, originating from intestinal absorption. Thus, the inclusion of mulberry hay substituting the concentrate in feedlot-lamb diets with better energy balancing might potentiate the use of this alternative source of nutrients as a result of the lower microbial protein synthesis, expressed in $\mathrm{M}_{\mathrm{N}} \mathrm{kg} \mathrm{RDOM}{ }^{-1}$ and $\mathrm{M}_{\mathrm{P}} \mathrm{kg}^{-1} \mathrm{TDN}$ (Table 4).

\section{Conclusions}

Inclusion of mulberry hay substituting the concentrate in feedlot-lamb diets reduced the synthesis of nitrogen compounds and the microbial efficiency and increased the excretion of nitrogen in the feces.

\section{Acknowledgment}

The authors would like to thank Fundação de Amparo à Pesquisa do Estado de São Paulo (FAPESP) for financing this study.

\section{References}

ANBARASU, C.; DUTTA, N.; SHARMA, K.; RAWAT, $\mathrm{M}$. Response of goats to partial replacement of dietary protein by a leaf meal mixture containing Leucaena leucocephala, Morus alba and Tectona grandis. Small Ruminant Research, Amsterdam, v. 51, n. 1, p. 47-56, 2004.

AZEVÊDO, J. A. G.; VALADARES FILHO, S. C.; PINA, D. S.; DETMANN, E.; VALADARES, R. F. D.; PEREIRA, L. G. R.; SOUZA, N. K. P.; SILVA, L. F. C. Consumo, digestibilidade total, produção de proteína microbiana e balanço de nitrogênio em dietas com subprodutos de frutas para ruminantes. Revista Brasileira de Zootecnia, Viçosa, MG, v. 40, n. 5, p. 10521060, 2011.

BA, N. X.; GIANG, V. D.; NGOAN, L. D. Ensiling of mulberry foliage (Morus alba) and the nutritive value of mulberry foliage silage for goats in central Vietnam. Livestock Research for Rural Development, Cali, v. 17, n. 2, p. 1-9, 2005.

BAMIKOLE, M. A.; IKHATUA, M. I.; IKHATUA, U. J.; EZENWA, I. V. Nutritive value of ulberry (Morus Spp.) leaves in the growing rabbits in Nigeria. Pakistan
Journal of Nutrition, Faisalabad, v. 4, n. 4, p. 231-236, 2005.

BRODERICK, G. A. Desirable characteristics of forage legumes for improving protein utilization in ruminants. Journal Animal Science, Champaign, v. 73, n. 9, p. 27602773, 1995.

CALDAS NETO, S. F.; ZEOULA, L. M.; PRADO, I. N.; BRANCO, A. F.; KAZAMA, R.; GERON, L. J. V.; MAEDA, E. M.; FERELI, F. Proteína degradável no rúmen na dieta de bovinos: digestibilidade total e parcial dos nutrientes e parâmetros ruminais. Revista Brasileira de Zootecnia, Viçosa, MG, v. 37, n. 6, p. 1094-1102, 2008.

CHEN, X. B.; GOMES, M. J. Estimation of microbial protein supply to sheep an cattle based on urinary excretion of purine derivatives: an overview of technical details. Aberdeen: Rowett Research Institute/ International Feed Research Unit, 1992. 21 p. (Ocasional Publiation).

COSTA, J. L.; RESENDE, H. Produção de feno de gramíneas. Juiz de Fora: EMBRAPA - CNPGL, 2006. 2 p. (EMBRAPA- CNPGL. Documentos, 19).

DETMANN, E.; QUEIROZ, A. C.; CECON, P. R.; ZERVOUDAKIS, J. T.; PAULINO, M. F.; VALADARES FILHO, S. C.; CABRAL, L. S.; LANA, R. P. Consumo de fibra em detergente neutro por bovinos em confinamento. Revista Brasileira de Zootecnia, Viçosa, MG, v. 32, n. 6, p. 1763-1777, 2003.

ETHERIDGE, R. D.; PESTI, G. M.; FOSTER, E. H. A comparison of nitrogen values obtained utilizing the Kjeldahl nitrogen and Dumas combustion methodologies (Leco CNS 2000) on samples typical of an animal nutrition analytical laboratory. Animal Feed Science and Technology, Amsterdam, v. 73, n. 1, p. 21-28, 1998.

EZEQUIEL, J. M. B.; SAMPAIO, A. A. M.; SEIXAS, J. R. C.; OLIVEIRA, M. M. Balanço de nitrogênio e digestão total da proteína e da energia de rações contendo farelo de algodão, levedura de cana-de-açúcar ou uréia em ovinos. Revista Brasileira de Zootecnia, Viçosa, MG, v. 29, n. 6, p. 2332-2337, 2000. Suplemento 2.

FERREIRA, D. F. Sisvar: a computer statistical analysis system. Ciência e Agrotecnologia, Lavras, v. 35, n. 6, p. 1039-1042, 2011.

GENTIL, R. S.; PIRES, A. V.; SUSIN, I.; NUSSIO, L. G.; MENDES, C. Q.; MOURÃO, G. B. Digestibilidade aparente de dietas contendo silagem de cana-de açúcar tratada com aditivo químico ou microbiano para cordeiros. Acta Scientiarum Animal Science, Maringá, v. 29, n. 1, p. 63-69, 2007. 
GERON, L. J. V.; MEXIA, A. A.; CRISTO, R. L.; GARCIA, J.; CABRAL, L. S.; TRAUTMANN, R. J.; MARTINS, O. S.; ZEOULA, L. M. Consumo, digestibilidade dos nutrientes e características ruminais de cordeiros alimentados com níveis crescentes de concentrado em ambiente tropical no Vale do Alto Guaporé - MT. Semina: Ciências Agrárias, Londrina, v. 34, n. 5, p. 2497-2510, 2013.

GOMES, R. A. Produção e valor nutricional de híbridos de amoreira (Morus alba L.) colhidos em diferentes idades de crescimento. 2012. Dissertação (Mestrado em Zootecnia) - Faculdade de Ciências Agrárias e Veterinárias. Universidade Estadual Paulista, Jaboticabal.

HALL, M. B. Neutral detergent-soluble carbohydrates: nutritional relevance and analysis. Gainesville: University of Florida, 2000. $76 \mathrm{p}$.

HOOVER, W. H.; MILLER-WEBSTER, T. K. Role of sugars and starch in ruminal fermentation. In: PROCEEDINGS TRI-STATE DAIRY NUTRITION CONFERENCE, 1998, Ohio. Proceedings... Ohio: Ohio State University, 1998. p. 1-16.

NATIONAL RESEARCH COUNCIL - NRC. Nutrients requirements of sheep. Washington: National Academies Press, 2007. 362 p.

PEREIRA, E. S.; ARRUDA, A. M. V.; MIRANDA, L. F.; MIZUBUTI, I. Y.; MUNIZ, E. B.; PINTO, A. P. Importância da inter-relação carboidrato e proteína em dietas de ruminantes. Semina: Ciências Agrárias, Londrina, v. 26, n. 1, p. 125-134, 2005.

PINA, D. S.; VALADARES, R. F. D.; VALADARES FILHO, S. C.; CHIZZOTTI, M. L. Degradação ruminal da proteína dos alimentos e síntese de proteína microbiana. In: VALADARES FILHO, S. C.; MARCONDES, M. I.; CHIZZOTTI, M. L.; PAUlinO, P. V. R. (Org.). Exigências nutricionais de zebuínos puros e cruzados BR - Corte. 2. ed. Viçosa, MG: UFV, 2010. p. 13-46.
RIBEIRO, P. R.; MACEDO JUNIOR, G. L.; SILVA, S. P. A review aspectos nutricionais da utilização da proteína pelos ruminantes. Veterinária Notícias, Uberlândia, v. 20, n. 2, p. 1-14, 2014.

SANCHEZ, M. D. Mulberry, an exceptional forage available almost worldwide. In: . (Ed.). Mulberry for animal production. Roma: FAO, 2002. p. 271-291.

SILVA, D. J.; QUEIROZ, A. C. Análise de alimentos: métodos químicos e biológicos. 5. ed. Viçosa, MG: Imprensa Universitária, 2002. 235 p.

SILVA, S. P.; RODRIGUES, M. T.; VIEIRA, R. A. M.; SILVA, M. M. C. Intake and performance simulation of goats fed exclusively Tifton 85 , mulberry or leucaena. Bioscience Journal, Uberlândia, v. 31, n. 3, p. 859-866, 2015.

SNIFFEN, C. J.; CONNOR, J. D.; VAN SOEST, P. J. A net carbohydrate and protein system for evalution cattle diets. II Carboydrate and protein availability. Journal of Animal Science, Champaign, v. 70, n. 11, p. 3562-3577, 1992.

VAN SOEST, P. J. Nutritional ecology of the ruminant. New York: Cornell University Press, 1994. 476 p.

VERBIC, J.; CHEN, X. B.; MACLEOD, N. A.; ØRSKOV, E. R. Excretion of purine derivatives by ruminants. Effect of microbial nucleic acid infusion on purine derivatives excretion by steers. Journal of Agricultural Science, Toronto, v. 114, n. 3, p. 243-248, 1990.

ZEOULA, L. M.; CALDAS NETO, S. F.; GERON, L. J. V.; MAEDA, E. M.; PRADO, I. N.; DIAN, P. H. M. Substituição do milho pela farinha de varredura de mandioca (Manihot esculenta, Crantz) em rações de ovinos: consumo, digestibilidade, balanços de nitrogênio e energia e parâmetros ruminais. Revista Brasileira de Zootecnia, Viçosa, MG, v. 32, n. 2, p. 491-502, 2003. 